\title{
Erupsi Gigi Sulung pada Anak dengan Riwayat Lahir Prematur, Berat Badan Lahir Rendah
}

\author{
Willyanti Soewondo, ${ }^{1}$ Sjarif Hidajat Effendi ${ }^{2}$ \\ ${ }^{1}$ Departemen Ilmu Kedokteran Gigi Anak Fakultas Kedokteran Gigi Universitas Padjadjaran Bandung, \\ ${ }^{2}$ Departemen Ilmu Kesehatan Anak Fakultas Kedokteran Universitas Padjadjaran \\ Rumah Sakit Dr. Hasan Sadikin Bandung
}

\begin{abstract}
Abstrak
Pertumbuhan dan perkembangan gigi merupakan bagian pertumbuhan dan perkembangan tubuh secara umum dan dipengaruhi faktor genetik dan lingkungan. Faktor lingkungan prenatal dapat mengakibatkan kelahiran prematur, bayi berat lahir rendah/BBLR, dan gangguan pertumbuhan perkembangan gigi. Tujuan penelitian ini untuk mengetahui waktu erupsi gigi sulung pada anak lahir prematur BBLR. Penelitian ini adalah studi potong lintang dilakukan pada bulan Januari sampai Juni 2009 di Rumah Sakit Gigi Mulut Fakultas Kedokteran Gigi Universitas Padjadjaran/RSGM FKG Unpad. Subjek penelitian yaitu anak usia 4-30 bulan, riwayat lahir prematur BBLR, dan lahir normal sebagai kontrol. Erupsi gigi sulung ditentukan berdasarkan jumlah gigi yang telah erupsi. Dengan teknik pengambilan sampel consecutive admission diperoleh 137 anak; 49 anak lahir prematur BBLR (usia gestasi $<37$ minggu, berat lahir $<2.500$ gram) dan 88 anak normal (usia gestasi 37-42 minggu, berat badan lahir >2.500 gram) sebagai kontrol. Dengan regresi korelasi linier dan uji-t student, hasil penelitian terdapat hubungan bermakna waktu erupsi dengan usia $(\mathrm{p}<0,01)$ Waktu erupsi gigi sulung pada anak lahir prematur BBLR secara bermakna lebih lambat daripada anak lahir normal $(p<0,01)$. Simpulan, waktu erupsi gigi sulung anak lahir prematur BBLR lebih lambat daripada anak lahir normal. [MKB. 2014;46(1):34-8]
\end{abstract}

Kata kunci: Bayi berat lahir rendah (BBLR), erupsi gigi sulung, lahir prematur

\section{Deciduous Teeth Eruption in Prematurely Born, Low Birth Weight Children}

\begin{abstract}
Growth and development of the teeth are parts of growth and development of the body. It is influenced by genetic and environmental factors. Prenatal environment might cause premature birth and disturbances of teeth development. The purpose of this research was to find out the time of deciduous teeth eruption in premature born children with low birth weight/LBW. This was a cross-sectional study, conducted in January to June 2009 in Dental Hospital Faculty of Dentistry Universitas Padjadjaran. Subjects were children aged 4-30 months with prematurely born low birth weight and normal birth weight as control. The technique was consecutive admissions; 49 prematurely born LBW children (gestational age $<37$ weeks, birth weight $<2,500$ grams) and 88 normal children (37-42 weeks gestational age, birth weight $>2,500$ grams). Deciduous teeth eruption was determinated by the number of erupted teeth. Linear corelation regression analysis and t- student test were used in this research. The results showed that there was a significant correlation between deciduous teeth eruption and age, $(\mathrm{p}<0.01)$ and deciduous teeth eruption in prematurely born children with LBW was significantly delayed $(p<0.01)$. In conclusion, deciduous teeth eruption in prematurely born LBW children was significantly delayed. [MKB. 2014;46(1):34-8]
\end{abstract}

Key words: Deciduous teeth eruption, low birth weight (LBW), prematurely born

Korespondensi: Dr. Willyanti Soewondo, drg., Sp.KGA(K), Departemen Ilmu Kedokteran Gigi Anak Fakultas Kedokteran Gigi Universitas Padjadjaran Bandung, Jalan Sekeloa Selatan 1 Bandung, mobile 0811200347, e-mail willyantir@yahoo.com 


\section{Pendahuluan}

World Health Organization/WHO menyatakan bahwa preterm birth (bayi lahir prematur) adalah bayi yang lahir pada usia gestasi atau kehamilan $<37$ minggu, low birth weight (LBW) atau bayi berat lahirrendah (BBLR) adalah bayi lahir dengan berat lahir $<2.500$ gram. Bayi prematur umumnya memiliki berat badan lahir di bawah 2.500 gram. Lahir prematur dengan BBLR mengakibatkan waktu perkembangan prenatal yang lebih pendek daripada seharusnya serta berisiko mengalami berbagai komplikasi neonatal dan masalah dalam perkembangan organ lainnya. ${ }^{1,2}$

Etiologi lahir prematur adalah multifaktorial berhubungan dengan faktor maternal, faktor janin, dan faktor yang tidak diketahui. Faktor maternal meliputi usia ibu melahirkan lebih dari 35 tahun, ibu muda, ibu perokok, hipertensi, preeklamsi, kehamilan multipel, dan infeksi. Infeksi dapat berlokasi pada gigi yang disebabkan oleh virus atau bakteri. Ibu yang mengalami periodontitis berisiko untuk melahirkan bayi prematur dan BBLR/LBW. Terdapat 3 kelompok bayi prematur berdasarkan berat yaitu LBW $<2.500$ gram, very low birth weight (VLBW) $<1.500$ gram; dan extremely low birth weight (ELBW) bila $<1.000$ gram. ${ }^{1}$

Penelitian sebelumnya menyatakan terdapat keterlambatan perkembangan fisik dan juga psikis bayi dengan riwayat prematur BBLR, demikian juga pada struktur jaringan oral yaitu terjadi gangguan pertumbuhan dan perkembangan pada gigi sulung maupun permanen yang dapat berupa anomali perkembangan seperti kelainan struktur email, palatal, dan ukuran gigi yang lebih kecil. ${ }^{2-4}$

Erupsi gigi merupakan suatu proses kompleks dan berkesinambungan dari rangkaian lingkaran hidup gigi, terdiri atas fase inisiasi, proliferasi, morfodiferensiasi, aposisi, kalsifikasi, dan juga erupsi. Pada gigi sulung sesudah erupsi akan diikuti dengan eksfoliasi, sedangkan pada gigi permanen erupsi merupakan fase terakhir. Erupsi merupakan salah satu indikator pertumbuhan dan perkembangan gigi. Pengetahuan tentang erupsi gigi normal sangat penting untuk mengetahui apakah keterlambatan atau percepatan erupsi itu disebabkan oleh faktor lokal atau genetik atau sistemik..$^{5,6,7}$

Tujuan penelitian ini untuk mengetahui waktu erupsi gigi sulung pada anak yang lahir prematur BBLR, yang penting untuk melihat pertumbuhan dan perkembangan gigi.

\section{Metode}

Subjek penelitian adalah anak dengan riwayat lahir prematur BBLR usia 4-30 bulan (lahir dengan usia gestasi $<37$ minggu, berat lahir $\leq 2.500$ gram) yang lahir di RS Dr. Hasan Sadikin Bandung, dan anak lahir dengan usia kehamilan cukup (usia gestasi $37-42$ minggu berat lahir $\geq 2.500$ gram) sebagai kontrol. Sebagai kriteria eksklusi yaitu anak dengan cacat bawaan. Pemeriksaan oral anak yang lahir prematur BBLR dilakukan pada saat kunjungan rumah dengan pencahayaan cukup menggunakan kaca mulut, sedangkan pemeriksaan kontrol dilakukan di klinik Rumah Sakit Gigi dan Mulut Fakultas Kedokteran Gigi Unpad/RSGM FKG Unpad, dan klinik gigi anak swasta selama periode Januari sampai Juni 2010. Dengan teknik sampling consecutive admission diperoleh 137 anak yang terdiri atas 49 anak lahir prematur BBLR dan 88 anak lahir normal. Sebanyak 49 anak lahir prematur terdiri atas 29 anak lahir prematur dengan kecil masa kehamilan $(\mathrm{KMK})$ /prematur BBLR dan sebanyak 20 anak lahir prematur dengan sesuai masa kehamilan (SMK)/prematur BBLR. Kecil masa kehamilan apabila bayi lahir dengan berat lahir di bawah persentil 10 pada kurva pertumbuhan intrauterin Lubchenco dilihat dari berat badan lahir dan usia gestasinya. ${ }^{1}$ Erupsi gigi sulung ditentukan berdasarkan jumlah gigi yang telah erupsi.

Prosedur penelitian ini dilakukan pemeriksaan fisis meliputi pemeriksaan intraoral untuk melihat gigi apa saja yang sudah erupsi. Penentuan lahir prematur dan berat badan lahir anak diperoleh dari catatan status kelahiran dan jawaban kuesioner ibu. Pada penelitian ini telah dilakukan koreksi usia untuk anak lahir prematur BBLR.

\section{Hasil}

Dengan teknik sampling consecutive admission diperoleh 137 anak terdiri atas 49 anak dengan lahir prematur BBLR yaitu yang lahir dengan usia gestasi $<37$ minggu dan berat badan lahir $<2.500$ gram, dan 88 anak normal adalah anak lahir dengan usia gestasi 37-42 minggu dan berat lahir $>2.500$ gram sebagai kontrol.

Tabel 1 dan 2 menunjukkan bahwa jumlah gigi rata-rata anak normal lebih banyak daripada anak prematur BBLR, sedangkan pada Tabel 3 menunjukkan tidak terdapat perbedaan bermakna jumlah gigi rata-rata pada anak prematur BBLR KMK dengan jumlah gigi rata-rata pada anak prematur BBLR SMK.

Analisis regresi korelasi linier dipergunakan untuk melihat hubungan erupsi gigi dengan lahir prematur BBLR memakai persamaan regresi:

Keterangan:

$$
\mathbf{Y}=\mathbf{a}+\mathbf{b x}
$$

$\mathrm{Y}=$ erupsi (jumlah gigi) 
Willyanti S.: Erupsi Gigi Sulung pada Anak dengan Riwayat Lahir Prematur, Berat Badan Lahir Rendah

Tabel 1 Jumlah Gigi Sulung Rata-rata berdasarkan Usia pada Anak Lahir Prematur BBLR dan Normal

\begin{tabular}{|c|c|c|c|c|}
\hline \multirow{2}{*}{$\begin{array}{c}\text { Usia } \\
\text { (bulan) }\end{array}$} & \multicolumn{2}{|c|}{ Anak Lahir Prematur BBLR } & \multicolumn{2}{|c|}{ Anak Lahir Normal } \\
\hline & $(n=49)$ & $\begin{array}{l}\text { Rata-rata } \\
\text { Jumlah Gigi }\end{array}$ & $(\mathrm{n}=\mathbf{8 8})$ & $\begin{array}{c}\text { Rata-rata } \\
\text { Jumlah Gigi }\end{array}$ \\
\hline 4 & 1 & - & 2 & 1 \\
\hline 5 & 1 & - & 2 & 1 \\
\hline 6 & 1 & - & 1 & 1 \\
\hline 7 & 1 & - & 1 & 1 \\
\hline 8 & 2 & - & 1 & 1 \\
\hline 9 & 6 & - & 4 & 2 \\
\hline 10 & 6 & - & 4 & 3 \\
\hline 11 & 4 & 0 & 4 & 4 \\
\hline 12 & 2 & 1 & 4 & 5 \\
\hline 13 & 4 & 1 & 4 & 5 \\
\hline 14 & 2 & 2 & 3 & 7 \\
\hline 15 & 3 & 3 & 3 & 9 \\
\hline 16 & 0 & 0 & 3 & 9 \\
\hline 17 & 1 & 4 & 4 & 11 \\
\hline 18 & 1 & 8 & 2 & 13 \\
\hline 19 & 1 & 7 & 2 & 14 \\
\hline 20 & 1 & 8 & 3 & 14 \\
\hline 21 & 2 & 9 & 3 & 16 \\
\hline 22 & 1 & 10 & 3 & 15 \\
\hline 23 & 1 & 11 & 10 & 16 \\
\hline 24 & 1 & 13 & 5 & 18 \\
\hline 25 & 1 & 14 & 5 & 17 \\
\hline 26 & 0 & - & 1 & 16 \\
\hline 27 & 0 & - & 2 & 19 \\
\hline 28 & 1 & 15 & 4 & 20 \\
\hline 29 & 2 & 16 & 4 & 20 \\
\hline 30 & 3 & 17 & 4 & 20 \\
\hline
\end{tabular}

$\mathrm{X}=$ usia (bulan), $\mathrm{a}=$ kostanta, $\mathrm{b}=$ koefisien regresi $\mathrm{Y}=-7428+0,788 \mathrm{x}$

Pada analisis regresi kolerasi linier diperoleh hubungan yang bermakna antara usia dan erupsi gigi baik pada anak normal maupun pada anak prematur BBLR, dengan derajat kepercayaan $95 \%(\mathrm{p}<0,01)$.

Uji-tstudent digunakan untuk membandingkan jumlah gigi rata-rata anak lahir normal dengan anak prematur BBLR. Jumlah gigi rata-rata yang telah erupsi antara anak lahir normal dan anak prematur BBLR terlihat perbedaan sangat bermakna (nilai $\mathrm{t}=6,33 ; \mathrm{p}<0,01$ ) yang artinya jumlah gigi rata-rata anak lahir normal bermakna lebih besar daripada anak lahir prematur BBLR. Hal ini berarti erupsi gigi sulung pada anak normal lebih cepat daripada anak lahir prematur BBLR atau erupsi gigi sulung pada anak lahir prematur BBLR lebih lambat daripada anak normal.

Jumlah gigi rata-rata pada anak lahir prematur BBLR KMK adalah 4, sedangkan jumlah gigi rata-rata anak prematur BBLR SMK adalah 5. Uji-t student digunakan untuk membandingkan 
Willyanti S.: Erupsi Gigi Sulung pada Anak dengan Riwayat Lahir Prematur, Berat Badan Lahir Rendah

Tabel 2 Jumlah Gigi Rata-rata pada Anak Lahir Prematur BBLR dan Normal

\begin{tabular}{lccc}
\hline & $\begin{array}{c}\text { Anak Lahir } \\
\text { Prematur } \\
\text { BBLR }\end{array}$ & $\begin{array}{c}\text { Anak Lahir } \\
\text { Normal }\end{array}$ & p \\
\hline $\mathrm{n}$ & 49 & 88 & \\
$\begin{array}{l}\text { Rata-rata } \\
\text { jumlah gigi }\end{array}$ & 5 & 11,53 & $<0,01$ \\
$\begin{array}{l}\text { Simpangan } \\
\text { baku }\end{array}$ & 5,9 & 6,57 & \\
\hline
\end{tabular}

jumlah gigi rata-rata anak lahir prematur BBLR KMK dengan jumlah gigi rata-rata anak lahir prematur BBLR SMK. Hasil uji-t menunjukkan $\mathrm{t}=-0,33$ dengan $\mathrm{p}>0,01$ yang berarti tidak terdapat perbedaan yang bermakna antara jumlah gigi ratarata anak lahir prematur BBLR KMK dan anak lahir prematur BBLR SMK. Hal ini berarti tidak terdapat perbedaan waktu erupsi gigi sulung anak lahir prematur KMK dengan anak lahir prematur SMK.

\section{Pembahasan}

Pertumbuhan/perkembangan gigi atau disebut juga odontogenesis terjadi pada waktu usia embrio intrauterin 4-5 minggu yang dengan proses berkesinambungan berupa inisiasi, proliferasi, morfodiferensiasi, aposisi, dan proses kalsifikasi disebut fase preerupsi dan fase erupsi. Erupsi merupakan proses kompleks berkesinambungan yang terdiri atas pergerakan preerupsi, tahapan intaroseus, penetrasi mukosa, tahapan preoklusal, dan tahapan oklusal. Erupsi gigi sulung yang kemudian akan diikuti oleh proses tanggalnya gigi sulung dan diikuti lagi dengan pergantian gigi

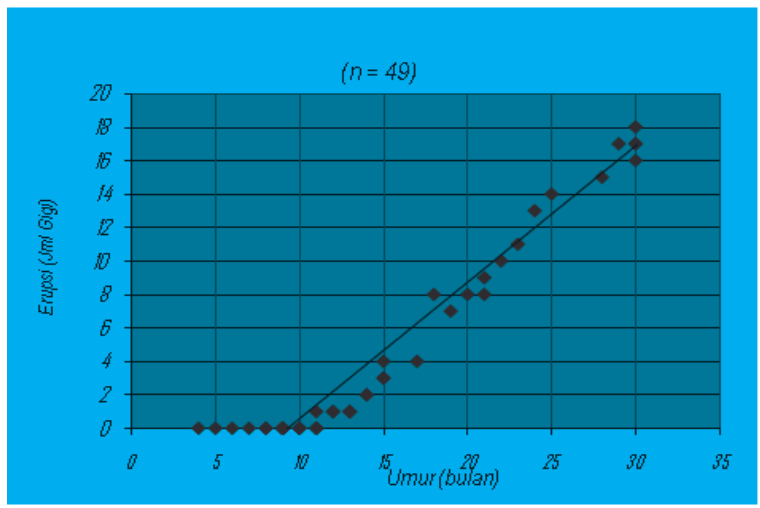

\section{Gambar Diagram Pencar Umur dengan Erupsi pada Anak Prematur BBLR}

Tabel 3 Jumlah Gigi Rata-rata pada Anak Lahir Prematur BBLR KMK dan SMK

\begin{tabular}{lccc}
\hline & $\begin{array}{c}\text { Anak Lahir } \\
\text { Prematur } \\
\text { BBLR } \\
\text { KMK }\end{array}$ & $\begin{array}{c}\text { Anak Lahir } \\
\text { Prematur } \\
\text { BBLR SMK }\end{array}$ & p \\
\hline $\mathrm{n}$ & 29 & 20 & \\
$\begin{array}{l}\text { Rata-rata } \\
\text { jumlah gigi }\end{array}$ & 4 & 5 & $>0,01$ \\
$\begin{array}{l}\text { Simpangan } \\
\text { baku }\end{array}$ & 5,2 & 6,8 & \\
\hline
\end{tabular}

permanen terjadi secara berurutan sesuai dengan usia anak. Waktu erupsi ini sangatlah bervariasi dan dipengaruhi oleh genetik, ras, etnik, serta faktor lingkungan. Kronologis erupsi gigi sulung lebih banyak dipengaruhi faktor genetik gigi permanen. , $^{5-10}$

Faktor lingkungan prenatal yang menyebabkan lahir prematurBBLRjuga menyebabkangangguan pertumbuhan/perkembangan gigi sulung karena masa kritis pertumbuhan dan perkembangan gigi sulung terjadi saat prenatal, sedangkan saat kritis pertumbuhan dan perkembangan gigi permanen terjadi saat pascanatal. ${ }^{5,7,8}$

Hasil penelitian ini memperlihatkan bahwa erupsi gigi sulung terjadi lebih lambat pada anak dengan riwayat lahir prematur BBLR. Erupsi pada anak prematur BBLR dimulai pada usia 12 bulan, sedangkan pada anak yang normal erupsi dimulai pada usia 4 sampai 6 bulan. Keterlambatan ini terjadi terutama pada erupsi gigi pertama sulung. Keadaan ini sesuai dengan penelitian sebelumnya bahwa lahir prematur BBLR berisiko mengalami hambatan perkembangan dan imaturitas organ termasuk gigi. ${ }^{2-4,8,9}$ Keterlambatan erupsi gigi sulung selain berhubungan dengan usia gestasi juga berhubungan dengan faktor saat lahir, yaitu apabila terjadi komplikasi yang memerlukan intubasi orotrakeal yang lama, sedangkan dengan patogenesisnya yang belum jelas, akan berisiko gangguan lokal pada pertumbuhan perkembangan gigi dan palatal. $., 5,8$

Telah banyak teori yang membahas erupsi gigi. Keterlambatan erupsi gigi itu berhubungan dengan hambatan pertumbuhan perkembangan gigi dalam tulang rahang, sehingga fase preerupsi yang terdiri atas proses inisiasi, proliferasi, morfodiferensiasi, aposisi, juga klasifikasi pun mengalami hambatan. Hal ini diikuti pula oleh terlambatnya fase penetrasi mukosa dan fase oklusal gigi sulung (fase erupsi) yang diikuti keterlambatan munculnya gigi dalam mulut. ${ }^{10}$

Faktor berat badan lahir bayi berpengaruh pula pada pertumbuhan perkembangan gigi, karena 
pembentukan gigi dipengaruhi oleh nutrisi saat prenatal, berat badan menunjukkan kecukupan nutrisi. Keterlambatan erupsi gigi sulung juga berhubungan dengan faktor nutrisi tidak adekuat yang merupakan faktor berpengaruh pada erupsi gigi. Seperti disebutkan pada penelitian Sjarif dkk. ${ }^{11}$ bahwa faktor berat badan lahir menentukan keparahan defek email gigi sulung yang akan erupsi pada anak dengan riwayat kecil masa kehamilan (KMK). Semakin kecil berat badan lahir bayi maka semakin parah defek email gigi sulungnya, tetapi semakin besar berat lahir bayi maka semakin ringan defek emailnya. ${ }^{11}$ Demikian pula halnya dengan waktu erupsi gigi, terlihat pada penelitian ini bahwa anak dengan berat lahir normal yaitu $>2.500$ gram mengalami erupsi gigi sulung yang lebih cepat daripada anak lahir prematur BBLR.

Pada penelitian ini tidak terdapat perbedaan yang bermakna antara erupsi gigi sulung pada anak lahir prematur BBLR KMK dan anak lahir prematur BBLR SMK. Hal ini disebabkan pada kedua kelompok terjadi gangguan pertumbuhan dan perkembangan gigi sulung karena masa kritis pertumbuhan dan perkembangan gigi sulung terjadi saat prenatal. ${ }^{6}$

Pada penelitian ini urutan erupsi gigi sulung pada anak prematur BBLR sama dengan anak berat lahir normal. Hal ini sesuai dengan pendapat Seow dkk. ${ }^{7}$ bahwa urutan erupsi pada anak prematur BBLR sama anak dengan berat lahir normal, hanya waktunya lebih lambat sekitar 6 bulan. Perbedaan waktu erupsi ini terjadi pada masa bayi sampai anak usia di bawah 6 tahun (early childhood) tetapi setelah usia 9 tahun (late childhood) tidak lagi ada perbedaan waktu erupsi gigi permanen anak lahir prematur BBLR dengan anak lahir normal. Hal ini, seperti juga pada organ lainnya, berhubungan dengan catch up growth.

Sebagai simpulan, waktu erupsi gigi sulung anak prematur BBLR lebih lambat daripada anak dengan berat lahir normal, erupsi dimulai saat 12 bulan.

\section{Daftar Pustaka}

1. Gomella TL, Cunningham MD, Eyal FG, Zenk KE. Neonatology, management, procedures, on-call problems, diseases, and drugs. Edisi ke-6, United States of America: Mc Graw-Hill; 2009. hlm. 23- 4.

2. Aldred Michael J, Crawford PJM, Cameron AC, Nigel K. Dental anomalies. Dalam: Cameron AC, Widmer RP, penyunting. Handbook of pediatric dentistry. Edisi ke-3. Philadelphia: Mosby; 2008. hlm. 267-9.

3. Liselotte P, Lars B, Bjorn S. A systematic review of the consequences of premature birth on palatal morphology, dental occlusion, tooth maturity and eruption. Angle Orthodontics. 2004;74:(2):269-79. (diunduh 8 Agustus 2006). Tersedia dari: http://www. ncbi.nlm.gov/pubmed/15132456.

4. Harila-Virpi, The effect of preterm birth on the development of the dentition, Department of Oral Development and Orthodontics, Institute of Dentistry, University of Oulu. Disertation 2004 (diunduh 8 Agustus 2006). Tersedia dari: http://www.herkules.oulu.fi/ isbn9514274393.

5. Eastman DL. Dental outcomes of preterm infants. Newborn Infant Nursing Rev. 2003; 3(3):93-8.

6. Mc Donald, Avery DR, Jean JR. Dentistry for the child and adolescent. Edisi ke-9. Philadelphia: Mosby Elsevier; 2011.

7. Seow KW, Young WG, Tsang A, Daley T. A study of primary dental enamel from preterm and fullterm children using light and scanning electron microscop. Pediat Dentistry. 2005;27(5):374-6.

8. Ramos SRP, Gugisch RC, Fraiz FC. The influence of gestational age and birth weight of the newborn on tooth eruption. J Applied Oral Sci. 2006;14(4):228-32.

9. Al-Syagh GD, Qasim AA, Al-Rawi BA. The effect of premature birth on the primary dentition. Al-Rafidain Dent J. 2008;8(1):1822.

10. Peedikayil FC, Delayed eruption; e-Journal of Dentistry. October-December 2011;1(Issue 4). (diunduh 10 November 2013). Tersedia dari: http://www.ejournal of dentistry.com.

11. Sjarif W, Oewen R, Effendi SH, Bambang S. Faktor ibu dan anak yang menentukan keparahan defek email gigi sulung pada anak dengan kecil masa kehamilan. MKI. 2010; 60(9):416-8. 